\title{
Access to healthcare services for people recovering from alcohol excess
}

\author{
Sarah Rhynas \\ From The European Academy of Nursing Science EANS Summer Conference \\ Barcelona, Spain. 8-9 July 2015
}

\begin{abstract}
Background
People recovering from alcohol excess can struggle to access healthcare services. Understandings of recovery need to be clarified in order to ensure services meet the needs of socially marginalised service users. In Scotland, alcohol excess is estimated to cost $£ 3.6 \mathrm{bn}$ annually (Scottish Government 2015) [1]. Ensuring that service users can access appropriate services is a national priority.
\end{abstract}

\section{Aims}

To explore the lives and give voice to people marginalised by alcohol related harm. To understand their experiences, support needs and relationships with the community.

\section{Methods}

The qualitative participatory approach of Photovoice (Wang \& Burris 1997) [2] was used to allow participants to use photography to tell their stories. The photos guided subsequent focus groups. Data were thematically analysed with input from participants. Findings were shared with policy-makers through exhibitions, events, conferences and writing.

\section{Results}

Participants shared insights into the importance of belonging to the community, contributing and negotiating the challenges of life in recovery. The value of peer support in preference to traditional health and social care services was emphasised. The importance of designing responsive services which improve the accessibility of healthcare for marginalised groups was highlighted.

\section{Conclusions}

Understanding the lives of people in recovery helps shape services. Providing peer support services within

Correspondence: sarah.rhynas@ed.ac.uk

School of Health in Social Science, University of Edinburgh, EH8 9JT, UK therapeutic social environments may be preferred by service users, ensuring their needs are met and healthcare is more accessible. Alcohol addiction is a national priority in Scotland but is relevant throughout Europe. Ensuring that services are accessible to users requires detailed understanding of their lives.

\section{Published: 8 October 2015}

\section{References}

1. Scottish Government: 2015, Alcohol Facts [http://www.gov.scot/Topics/ Health/Services/Alcohol].

2. Wang C, Burris MA: Photovoice: Concept, Methodology, and Use for Participatory Needs Assessment. Health Education \& Behaviour 1997, 24(3):369-387.

doi:10.1186/1472-6955-14-S1-S6

Cite this article as: Rhynas: Access to healthcare services for people recovering from alcohol excess. BMC Nursing 2015 14(Suppl 1):S6.

\section{Submit your next manuscript to BioMed Central and take full advantage of: \\ - Convenient online submission \\ - Thorough peer review \\ - No space constraints or color figure charges \\ - Immediate publication on acceptance \\ - Inclusion in PubMed, CAS, Scopus and Google Scholar \\ - Research which is freely available for redistribution \\ Submit your manuscript at www.biomedcentral.com/submit}

